\title{
Penguatan Ketangguhan Modal Sosial Kelompok Nenas Berduri Akibat Pandemi Covid-19 Di Desa Rimbo Panjang Kecamatan Tambang Kabupaten Kampar
}

\author{
Resdati $^{1}$, Syafrizal ${ }^{2}$, Achmad Hidir $^{3}$, T. Romi Marnelly ${ }^{4}$ \\ 1,2,3,4 Fakultas IImu Sosial dan IImu Politik, Universitas Riau \\ Email: syafrizal@lecturer.unri.ac.id; resdati@lecturer.unri.ac.id
}

\begin{abstract}
Abstrak
Perkembangan jaman telah menuntut kelompok masyarakat nenas berduri ( POKMAS) di desa Rimbo Panjang untuk terus dapat mengembangkan dan mengoptimalkan berbagai upayanya dalam mempertahankan usaha produksinya agar tetap produktif di masa pandemi Covid-19. Sasaran kegiatan pengabdian ini di lakukan kepada masyarakat di Desa Rimbo Panjang Kabupaten Kampar khususnya anggota kelompok masyarakat nenas berduri (POKMAS), data yang di peroleh di lapangan di hasilkan melalui wawancara dan observasi terhadap sebuah kelompok masyarakat nenas berduri (POKMAS) yang memproduksi olahan nenas berduri, adapun pendekatan yang di gunakan dalam pengabdian ini adalah sosialisasi, dan setelah melalui beberapa pengamatan yang telah di lakukan maka team pengabadian dapat menarik beberapa kesimpulan di antaranya adalah, pertemuan dengan kelompok pelaku usaha nenas berduri dalam bentuk sosialisasi dan pelatihan. Kegiatan awal yang dilakukan berupa diskusi dan sosialisasi terkait permasalahan dalam kelompok pelaku usaha nenas berduri terkait kendala kegiatan usaha serta dalam pengembangan modal sosial untuk usaha nenas. Setelah itu dilakukan pelatihan pemberdayaan masayrakat nenas berduri berupa penguatan modal sosial yang terdiri dari norma, jaringan dan kepercayaan (trust) dalam pengembangan usaha, di sisi lain kelompok pelaku usaha nenas berduri mengalami kendala yakni adanya wabah pandemic Covid-19 sehingga menyebabkan kerugian pada kelompok usaha nenas berduri, Pelaku usaha nenas berduri mengalami kerugian karena hasil olahan buah nanas pedagang yang tidak laris terjual sehingga menyebabkan membusuk. Modal yang dikeluarkan untuk membeli nenas tidak sebanding dengan jumlah keuntungan yang diperoleh dalam pembelian nanas pada petani nenas.
\end{abstract}

Kata Kunci: Penguatan Modal Sosial, Ketangguhan Modal, Rimbo Panjang

\section{Pendahuluan}

Indonesia sebagai negara agraris (pertanian) yang di dukung oleh faktor-faktor geografis, demografis, topografis diantaranya memiliki pulau-pulau dan tetap menyebar dikhatulistiwa dengan cuaca beriklim tropis dan dipengaruhi oleh angin monsom barat dan angin monsom timur serta diapit oleh 2 samudera yakni samudera hindia dan samudra pasifik. Hal ini menyebabkan Kawasan Indonesia menjadi kawasa strategis dan kaya akan sumber daya alam. Salah satu kekayaan alam Indonesia adalah buah nenas yang merupakan komoditi hortikultura yang sangat potensial menjadi komoditi sekaligus khas bagi provinsi riau. salah satu daerah sentra penghasil nanas terbesar adalah Kabupaten Kampar. Kabupaten Kampar merupakan salah satu sentra penanaman nenas di Provinsi Riau dengan produksi 13.460,41 ton (Syafrizal \& Resdari, 2021; Achmad, 2021) sentra pengembangan nenas di Kabupaten Kampar berpusat pada kecamatan tambang dan salah satunya berada pada Desa Rimbo Panjang dan Kualu Nenas daerah ini adalah lahan gambut sehingga cocok untuk ditanami jenis tumbuhan ini. Adapun luas areal budidaya nenas adalah $500 \mathrm{Ha}$ dan $1050 \mathrm{Ha}$ (BPP Tambang, 2013) pada tahun 2013 dengan jumlah produksi nenas di Kecamatan Tambang berjumlah 12.750 ton, yang dihasilkan dari 13.250 .000 pohon nenas (BPS Kampar, 2014) dengan hamparan kebun nenas yang luas, nanas sangat mudah dijumpai di sepanjang desa rimbo panjang, jalan lintas pekanbaru-bangkinang.

Nenas menjadi salah satu komoditas utama tanaman yang buahnya banyak ditanam di Desa Rimbo Panjang serta buahnya belum di manfaatkan untuk olahan makanan. Desa Rimbo panjang 
terkenal dengan Desa Nenas, bisa dilihat dari Icon Desa berupa Tugu Nenas, dari dahulu hingga sekarang masyarakat Desa RimboPanjang masih tetap memiliki Perkebunan nanas aktif, namun nanas yang ada di Desa masih dijual dalam bentuk buah dan dijual ke tengkulak, sehingga pendapatan petani nenas tidak begitu menguntungkan petani. Buah nenas ini kerap di jadikan olahan makanan mulai dari stik, selai, sirup, sari nenas, dodol dan olahan lainnya namun masih dalam skala rumahan dan belum merata pengolahannya. Peluang usaha pengolahan buah nenas ini memang sangat menjanjikan khususnya di Desa Rimbo Panjang. Dimana selain komoditas utama nya, Pengolahan Prudes (Nanas) ini memiliki peluang yang masih terbuka lebar. Keuntungan yang di dapat dalam Pengolahan Prudes (Nanas) ini memang memiliki keuntungan yang bernilai besar (Dadi, 2020).

Harga yang ditawarkan para pedagang pun bervariasi. Ada nenas yang diikat setiap sepuluh biji bisa dijual Rp 15.000,- saja, namun ada juga yang dijual secara eceran. Menurut pedagang nanas akan laku pada saat musim liburan yang dijadikan sebagai oleh-oleh sebaliknya pedagang akan mengalami sepi onset penjualan pada saat tidak musim liburan. Sejumlah pedagang nanas mengalami kerugian karena sepi pembeli bahkan menyebabkan buah nanas menjadi busuk bahkan hampir 400-an buah nanas pedagang yang membusuk. modal yang dikeluarkan untuk membeli nanas tidak sebanding dengan jumlah keuntungan yang diperoleh dalam pembelian nenas pada petani nanas (Syafrizal \& Resdati, 2020; Dadi, 2019; Dadi, 2020).

Ibu-ibu di Desa Rimbo Panjang sudah pernah mengikuti pelatihan pembuatan Sirup nanas, Dodol nanas dan Sari Buah nenas yang ditaja oleh BALATMAS Provinsi Riau. Mereka sudah mengikutkan produk unggulan ini dalam Even-even yang ada diprovinsi maupun Kabupaten, namun karena masih belum ada izin edarnya mereka belum bisa produksi massal. Selain itu kelompok juga masih melalui kelompok PKK Desa belum ada Kelompok khusus. Dari pengalaman masyarakat yang sudah pernah memasukkan beberapa kali Sirup ini ke Minimarket, prospeknya sangat bagus, namun karena belum ada izin edar mini market kurang melirik untuk mengambil produk tersebut, dari pengalaman ini Desa Rimbo Panjang membentuk kelompok masyarakat Nenas Berduri dengan tujuan untuk mengembangkan lagi produk Unggulan Desa Rimbo Panjang ini yang sesuai dengan Icon Desa Rimbo Panjang.

Desa ini pernah mendapat kunjungan dari Pemerintahan Norwegia, Presiden Ir.Jokowi dan Mantan Presiden SBY sehingga berpotensi untuk dikembangkan produk unggulan daerahnya, Selain itu kedatangan Presiden bersama rombongan ke desa di pinggir Kota Pekanbaru yang langganan terbakar ini menjadi salah satu titik penting yang menandai keseriusan pemerintah dalam mengatasi kebakaran hutan dan lahan. Namun memasuki beberapa tahun ke belakang ini para pengusaha nenas di Desa Rimbo Panjang mengalami kendala dalam memasarkan olahan nenas tersebut, hal ini tentunya di akibatkan semenjak adanya wabah pandemi Covid-19 sehingga menyebabkan kerugian pada kelompok usaha nenas berduri, pelaku usaha nenas berduri mengalami kerugian karena hasil olahan buah nanas pedagang yang tidak laris terjual sehingga menyebabkan membusuk. Modal yang dikeluarkan untuk membeli nanas tidak sebanding dengan jumlah keuntungan yang diperoleh dalam pembelian nenas pada petani nanas, hasil olahan stik nanas dan dodol nanas mengalami kerugian karena kurang dilirik oleh pembeli, Produksi menumpuk dan penjualan cenderung tidak merangkak naik hal ini akibat pandemi COVID-19.

Masa pandemi Covid-19 yang mengharuskan seluruh masyarakat untuk beradaptasi dengan kebiasaan baru pun menjadikan segala aspek kehidupan masyarakat memiliki perubahan yang signifikan termasuk didalamnya sosial ekonomi masyarakat. Melihat pada pelaku usaha nanas di Provinsi Riau yang memiliki perbedaan perubahan dalam sosial ekonominya, seperti petani nanas di desa Penyengat Kabupaten Siak Provinsi Riau mendapatkan keuntungan berlipat saat pandemi Covid-19 karena pemasarannya hingga keluar daerah namun berbeda halnya dengan apa yang terjadi di di Desa Rimbo Panjang yakni mendapatkan penurunan omset dan terancam kehilangan penghasilan. Berdasarkan penuturan ketua kelompok masyarakat nenas berduri. Badan Restorasi Gambut (BRG)-Kemitraan yang selama ini menjadi pendamping dan melakukan pembinaan telah berhenti menjalankan tugas di desa Rimbo Panjang sehingga membuat aktifitas di kelompok Masyarakat Berduri sulit bangkit kembali dan kurang berproduktifitas.

Modal sosial memiliki beberapa elemen yang merupakan sumber dan energy bagi masyarakat. Beberapa elemen modal sosial antara lain kepercayaan (trust), nilai dan norma timbal balik, institusi 
dan asosiasi, hubungan timbal balik serta jaringan. Modal sosial terdapat juga pada perdagangan. Berbicara tentang perdagangan maka orang tidak akan lupa dengan pembahasan tentang kewirausahaan (entrepreneurship) (Sidiq \& Achmad, 2020; Sidiq et al., 2021). Seperti penelusuran Berger dalam (Damsar, 2016) ekonom memandang kewirausahaan sebagai suatu akibat dari suatu konstelasi pada suatu kondisi ekonomi tertentu, daripada sebagai suatu penyebab bagi pertumbuhan ekonomi. Berger melanjutkan bahwa para ekonom seperti Albert Hirschman dan Alexander Gerschenkron cendrung mengabaikan arti dari kewirausahaan. Mereka mengatakan jika kondisi ekonomi tidak cocok, maka kewirausahaan tidak akan muncul dan masyarakat tetap akan stagnan. Berbeda dengan para ekonom, sebagai sosiolog Light dan Rosenstein (Damsar, Indrayani. 2016) melihat kewirausahaan sebagai suatu variabel yang melekat erat dalam sumber-sumber sosial budaya seperti pola tindakan yang diorientasikan secara sosial, jaringan sosial dan modal sosial. Oleh sebab itu ketika membicarakan pola tindakan ekonomi yang diorientasikan secara sosial misalnya, saat itu perbincanggan kewirausahaan telah dimulai. Aktifitas ekonomi yang dimotivasi oleh orientasi nilai baik yang bersumber dari agama maupun dari adat seperti amanah (accountability), tablig memberikan informasi yang benar), sidik (jujur), fathonah (cerdik dalam melihat sesuatu), kesederhanaan (moderation), berhemat (parsimony) dan menjauhi pemborosan (extravagance).

Orientasi nilai yang demikian akan menghasilkan kepercayaan (trust) dalam interaksi dan transaksi bisnis. Kemampuan melakukan hal ini sehingga kepercayaan bisa diperoleh dipandang sebagai modal sosial. Kewiraswastaan merupakan produk dari suatu proses sosial budaya. Sumber modal sosial bukanlah berasal dari sumber modal lainnya yang biasanya kita ketahui berasal dari pinjaman bank, pemerintah, dan lain-lain (Prawira et al., 2021; Sudrajat et al., 2018). Namun yang dimaksud sebagai sumber modal sosial merupakan berasal dari hubungan-hubungan atau relasi sosial yang pastinya harus ada koneksi dengan orang lain, maksudnya harus memiliki hubungan antar satu sama lain. Objek-objek yang menjadi tempat dari relasi-relasi sosial ini mulai dari orang (individu) yang akan menjalin hubungan sosial, kemudian kelompok (group), komunitas-komunitas dan terakhir sampai pada masyarakat luas. Keempat objek tersebut sama-sama memiliki peranan yang penting dalam modal sosial.

Relasi-relasi sosial tersebut harus diambil manfaat sosial serta manfaat ekonominya. Apabila manfaat dan keuntungan tidak diambil maka relasi-relasi sosial itu tidak digolongkan sebagai modal sosial, namun hanya sebatas interaksi dan ekspresi antara individu satu dengan yang lain. Pemanfaatan sumber daya yang berwujud relasi-relasi sosial secara sosialnya bisa mempererat hubungan dalam hal kerjasama, secara politik bisa membuat tawar politik posisinya jadi lebih kuat, dan selanjutnya secara ekonomi untuk memperoleh profit walaupun bisa jadi profitnya tidak terlalu berarti.

Partisipasi berarti prakarsa, peran aktif dan keterlibatan semua pelaku pembangunan termasuk penyedia dan penerima pelayanan, serta lingkungan sosial dalam mengambil keputusan, perumusan rencana, pelaksanaan kegiatan untuk pemantauan pelaksanaan untuk meningkatkan kesejahteraan sosial. Prakarsa dan peran serta secara aktif anggota masyarakat dalam berbagai kegiatan pembangunan masyarakat. Kegiatan partisipasi masyarakat dalam pembangunan meliputi identifikasi potensi, permasalahan yang dihadapi masyarakat, penyusunan program-program pembangunan yang benar-benar dibutuhkan masyarakat lokal, implementasi program pembangunan dan pengawasannya. Partisipasi masyarakat dalam pembangunan yang diarahkan dan dilakukan dalam lingkungan masyarakat pedesaan setempat berarti orientasi pembangunan adalah ke dalam (inward looking strategi), karena anggota masyarakat dianggap sebagai pihak yang paling mengetahui potensi dan kondisi masyaraatnya. (Adisasmita, 2006).

Menurut Raharjo Adisasmita (2006) partisipasi anggota masyarakat adalah keterlibatan anggota masyarakat dalam pembangunan, meliputi kegiatan dalam perencanaan dan pelaksanaan (implementasi) program/proyek pembangunan yang dikerjakan masyarakat local. Istilah partisipasi pada umumnya bermakna mengajak masyarakat untuk turut bekerja atau melaksanakan suatu kegiatan yang ditujukan untuk kepentingan masyarakat itu sendri. Defenisi lain dikemukan oleh taliziduhu (dalam Remiswal, 2009:24) bahwa partisipasi adalah kesediaan untuk membantu berhasilnya setiap program dengan kemampuan setiap orang tanpa berarti mengorbankan diri sendiri (Adisasmita, 2006). 
Damsar (2011) telah menelusuri berbagai kajian tentang partisipasi masyarakat dari berbagai ahli. Dari kajian tersebut Damsar telah merumuskan beberapa faktor/variable yang mempengaruhi orang dalam partisipasi diantaranya meliputi, (1) pendidikan yang dimiliki oleh seseorang dipandang bisa mempengaruhi partisipasi seseorang dipandang dalam berbagai kegiatan public, (2) Pekerjaan seseorang memberikan suatu ruang dan waktu tertentu bagi orang tersebut untuk ikut serta dalam kegiatan politik, pekerjaan tertentu membatasi seeorang untuk berpartisipasi dalam kegiatan publik dikarenakan variasi pekerjaan, (3) pendapatan diperoleh karena seseorang melakukan pekerjaan. Pendapatan biasanya dipandang sebagai premium dalam keikutsertakan pada lingkungan publik, (4) partisipasi masyarakat desa dilaksanakan melalui upaya pengembangan kemandirian dan kesejahteraan masyarakat dengan meningkatkan pengetahuan, sikap keterapilan, perilaku, kemampuan, kesadaran, serta memanfaatkan sumber daya melalui penetapan kebijakan, program kegiatan, pendampingan sesuai dengan esensi masalah dan prioritas kebutuhan masyarakat.

Adapun bentuk-bentuk partisipasi masyarakat menurut Kunyanti \& Mujiono (2021) dan Syafrizal (2019) diantaranya yakni, (1) Partisipasi buah pikiran berupa sumbangan ide baik yang digunakan dalam menyusun program maupun dalam memperlancar pelaksanaan program dan juga untuk mewujudkannya dengen memberikan pngetahuan serta pengalaman untuk mengembangkan suatu kegiatan yang dilaksanakan (2) Partisipasi tenaga yakni partisipasi dalam bentuk tenaga untuk berbagai kegiatan seperti perbaikan atau pembangunan desa, pertolongan bagi orang lain dan sebagainya yang bertujuan untuk menunjang keberhasilan program (3) Partisipasi harta benda yang diberikan masyarakat dalam menymbang harta benda, seperti perkakas atau alat-alat kerja sehngga proses pembangunan dapat dilaksanakan serta dapat juga memberikan sumbangan berupa modal (uang) (4) Partisipasi keterampilan dan kemahiran dilakukan untuk mendorong keterampilanketerampilan yang dimiliki masyarakat (5) Partisipasi sosial yang diberikan orang sebagai tanda paguyuban.

Berdasarkan UU Nomor 20 tahun 2008, prinsip pemberdayaan Usaha Mikro, Kecil, dan Menengah adalah sebagai berikut (1) Penumbuhan kemandirian, kebersamaa, dan kewirausahaan Usaha Mikro, Kecil, Menengah untuk berkarya dengan prakarsa sendiri, (2) Perwujudan kebijakan publik yang transparan, akuntabel, dan berkeadilan. (3) Pengembangan usaha berbasis potensi daerah dan berorientasi pasar sesuai dengan kompetensi Usaha Mikro, Kecil, dan Menengah. (4) Peningkatan daya saing Usaha Mikro, Kecil, dan Menengah. dan sebagai (5) Penyelenggaraan perencanaan, pelaksanaan, dan pengendalian secara terpadu. Sedangkan, tujuan dari pemberdayaan Usaha Mikro, Kecil, dan Menengah menurut UU Nomor 20 tahun 2008 adalah sebagai berikut (1) Mewujudkan struktur perekonomian nasional yang seimbang, berkembang dan berkeadilan. (2) Menumbuhkan dan mengembangkan kemampuan Usaha Mikro, Kecil, dan Menengah menjadi usaha yang tangguh dan mandiri. (3) Meningkatkan peran Usaha Mikro, Kecil, dan Menengah dalam pembangunan daerah, penciptaan lapangan kerja, pemerataan pendapatan, pertumbuhan ekonomi. Dan pengentasan rakyat dari kemiskinan.

Adapun strategi kebijakan pemberdayaan UKM, agar mampu bersaing dengan pelaku ekonomi lainnya dapat berupa (Athhoff, 2013) (1) Kebijakan dukungan penguatan bersifat keuangan, ditujukan agar UKM memperoleh kemudahan dalam mengakses sumber-sumber pembiayaan modal usaha dengan cara penyederhanaan skim kredit bagi UKM. (2) Kebijakan pemberian dukungan penguatan bersifat non keuangan, seperti pengembangan kualitas SDM, pengadaan pemberdayaan Pos Ekonomi Rakyat (PER). Tujuan akhir dari pemberdayaan yakni tercapainya peningkatan kesejahteraan masyarakat. Hal ini mengingat UKM merupakan sektor ekonomi yang paling berkontribusi besar terhadap perekonomian masyarakat. Dampak keberadaan UKM terhadap masyarakat sekitar bisa bersifat langsung dan tidak langusng. Bersifat langsung, maksudnya manfaat yang diperoleh masyarakat yang bekerja dan memperoleh imbalan langsung dari UKM baik berupa gaji maupun upah. Sedangkan pengaruh tidak langsung berupa dampak positif dari keberadaan UKM terhadap masyarakat sekitar yang bukan pekerja di UKM tersebut misalnya efek keterkaitan konsumsi: seperti peningkatan daya beli dan konsumsi kebutuhan pekerja UKM akan mendorong ekonomi lokal di lingkungan UKM berada. Hal ini dikenal dengan istilah multiplier effect atau efek pengganda dalam ekonomi. Kesejahteraan UKM bisa diukur dari tambahan kepemilikan aset UKM, peningkatan pembangunan manusia dan kualitas hidup (Damsar, 2009; Damsar, 2015; Dadi, 2021).

Penguatan Ketangguhan Modal Sosial Kelompok Nenas Berduri Akibat Pandemi Covid-19 Di Desa Rimbo Panjang Kecamatan Tambang Kabupaten Kampar (Resdati, dkk) 
Agribisnis pada hakekatnya adalah keterkaitan meyeluruh atas aktivitas yang bertujuan pada bidang bisnis, penakannya terhadap perusahan atau bentuk unit usaha, siklus input, jasa pengangkutan, jasa keuangan, teknologi budidaya, output produksi, dan agro base industri yang berorientasi pada pasar untuk memperoleh keuntungan. Pembangunan ekonomi pedesaaan tidak terlepas dari pendekatan dengan manajemen dan agribisnis pada sector pertanian yakni usaha tani pertanian berorientasi bisnis, pendalalaman untuk operasional secara optimal dapat dimaknai dan mempertimbangkan seperti dikemukakan oleh Soerkawi 2005 atas factor-faktor sebagai berikut, (1) Pemanfaatan teknologi (technological endowment) (2) Pemanfaatan institusi (kelembagaan yang saling menguntungkan (institutional endowment) (3) Pemanfaatan budaya (cultural endowment) (4) Pemanfaatan sumber daya (resourse endowment) (Basem, 2015; Dadi, 2014; Dadi, 2020).

Berdasarkan analisis situasi yang ada dan sedang terjadi di Desa Rimbo Panjang Kecamatan Tambang Kabupaten Kampar,terhadap kegiatan Penguatan Modal Sosial Kelompok Masyarakat (POKMAS) Nenas berduri akibat Pandemi Covid-19 di Desa Rimbo Panjang Kecamatan Tambang Kabupaten Kampar adalah sebagai berikut:

a. Pelaku usaha nanas mengalami kerugian karena buah nanas pedagang yang tidak laris terjual sehingga menyebabkan buah nanas membusuk. modal yang dikeluarkan untuk membeli nanas tidak sebanding dengan jumlah keuntungan yang diperoleh dalam pembelian nanas pada petani nanas.

b. Hasil olahan stik nanas dan dodol nanas mengalami kerugian karena kurang dilirik oleh pembeli akibat pandemic Covid-19

c. Badan Restorasi Gambut (BRG)-Kemitraan sebagai mitra kelompok masyarakat (Pokmas) nenas berduri telah berakhir di desa Rimbo Panjang sehingga kelompok masyarakat nenas berduri perlu dukungan adanya mitra untuk membangkitkan usaha kembali khususnya akibat Pandemi Covid-19..

Masyarakat sasaran adalah masyarakat yang bertempat tinggal di Desa Rimbo Panjang yakni Kelompok Masyarakat (POKMAS) Nenas Berduri Di Desa Rimbo Panjang Kecamatan Tambang Kabupaten Kampar. Dipilihnya kelompok sasaran tersebut dengan pertimbangan peran mereka sebagai pelaku usaha yang sesuai dengan potesi produk unggulan Desa Rimbo Panjang yakni buah nanas sehingga diharapkan dapat menjadi desa unggul dalam produktifitas dalam pengolahan nenas.

a. Penguatan ketangguhan modal sosial Kelompok masyarakat usaha nenas berduri di desa Rimbo Panjang sehingga manpu melakukan pemasaran antar pulau, peningkatan dalam jumlah produk, peningkatan omset dan kemampuan manajemen menghadapi berbagai kendala produksi, contohnya ketika menghadapi situasi sulit seperti masa pandemi secara global.

b. Mengembangkan usaha nanas berduri menjadi produk unggulan desa rimbo panjang sehingga menjadi sentra produksi nanas.

Adapun tujuan dari kegiatan pengabdian Kepada Masyarakat ini :

a. Mengatasi kendala yang dihadapi oleh Kelompok Masyarakat (POKMAS) Nenas Berduri Akibat Pandemi Covid-19 Di Desa Rimbo Panjang Kecamatan Tambang Kabupaten Kampar

b. upaya Penguatan ketangguhan modal sosial Kelompok Masyarakat (POKMAS) Nenas Berduri Akibat Pandemi Covid-19 Di Desa Rimbo Panjang Kecamatan Tambang Kabupaten Kampar

\section{Realisasi Kegiatan}

Metode pendekatan yang digunakan dalam mengatasi permasalahan yang dihadapi oleh mitra dari kegiatan pengabdian masyarakat ini adalah melalui Pelatihan dan pembinaan langsung dan terarah dengan memberikan kesempatan untuk berpartisipasi langsung dalam kegiatan tersebut. Adapun langkah-langkahnya adalah sebagai berikut:

\subsection{Langkah-langkah Kegiatan}

Bentuk kegiatan pengabdian yang akan dilakukan dalam 2 tahun adalah sebagai berikut: 
Tabel 1.

Prosedur Kegiatan

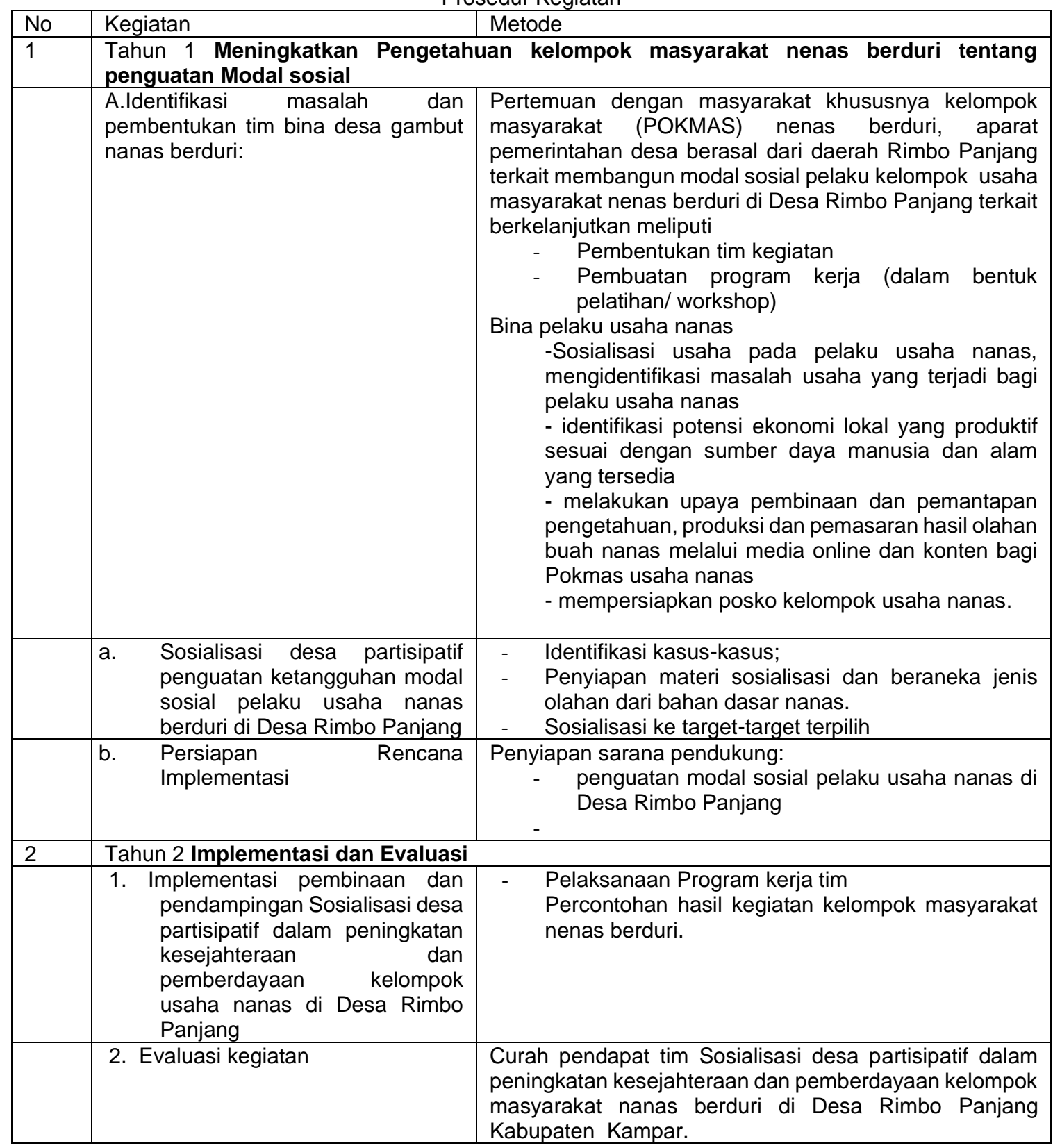

Kegiatan ini dilakukan melalui pertemuan dengan pelaku usaha nanas dalam bentuk sosialisasi dan pelatihan. Kegiatan awal yang dilakukan berupa diskusi dan sosialisasi terkait permasalahan dalam pelaku usaha nanas terkait kendala pertanian dan perkebunan serta usaha dalam pengembangan usaha nanas. Partisipasi mitra dalam kegiatan pengabdian pada masyarakat ditunjukkan dengan adanya dukungan berupa kesanggupan kerja sama sebagai mitra dengan tim dari Universitas Riau dalam penerapan sehingga akhirnya terciptalah Desa Binaan Rimbo Panjang menjadi desa yang memiliki produk unggulan buah nanas dengan pengutan ketangguhan modal sosial Kelompok Masyarakat Nenas Di Desa Rimbo Panjang Kecamatan Tambang Kabupaten Kampar. 


\section{Tinjauan Hasil Yang Dicapai}

\subsection{Profil Desa Rimbo Panjang}

Desa Rimbo panjang berbatasan langsung denga kota Pekanbaru, membentang jalan menuju ke arah bangkinang sekitar $10 \mathrm{~km}$ sebagai lbu Kota kabupaten Kampar. Berdasarkan monografi desa, luas Desa Rimbo Panjang yaitu 7.967.68 Ha, lahan pertanian sekitar $9000 \mathrm{Ha}$. Pada mulanya Desa Rimbo Panjang dominan hutan dan rawa. Mulai tahun 1951, desa ini ditempati oleh penduduk dari Sumatera Barat. Pengusulan nama Desa Muda tahun 1971 sampai tahun 1974. Tahun 1979, menjadi desa definitif menjadi Rimbo Panjang. Kehidupan di Desa Rimbo Panjang adalah pertanian dan perkebunan. Hasil produksi pertanian adalah Nenas, Karet dan Sawit, selain itu juga mempunyai penghasilan tambahan adalah tenak Sapi dan Tambak Ikan Lele. Perkembangannya pada daerah permukiman, dan industri.

\section{2. Profil Kelompok Masyarakat Nenas Berduri}

Terdapat sebuah kelompok masyarakat yang bernama POKMAS nenass berduri, dimana kelompok tersebut di Ketuai oleh Ibu Desi Muliati, S.Pt dan pernah mendapat pendampingan dari BRG-Kemitraan namun BRG-Kemitraan telah berakhir semenjak akhir tahun 2020. Usaha POKMAS nenas berduri menjual berbagai hasil olahan buah nanas, seperti dodol nanas, stik nanas, sirup nanas, pizza nanas, rendang nanas, cake nanas. Peluang usaha pengolahan buah nanas ini memang sangat menjanjikan khususnya di Desa Rimbo Panjang. Dimana selain komoditas utama nya, Pengolahan Prudes (Nenas) ini memiliki peluang yang masih terbuka lebar. Keuntungan yang di dapat dalam Pengolahan Prudes (Nenas) ini memang memiliki keuntungan yang bernilai besar.

\subsection{Tingkat Kesejahteraan Petani di Desa Rimbo Panjang}

Dari hasil studi literatur dan wawancara kami simpulkan bahwa secara umum tingkat kesejahteraan petani di Rimbo Panjang yang menjadi sasaran kegiatan pengabdian ini berada pada level menengah, kemudian berdasarkan tingkat pendidikan, hampir sebagian besar masyarakat Desa Rimbo Panjang masih memiliki pendidikan yang menengah khususnya orang tua dan pemuda produktif. Sebagaimana kebiasaan dan kondisi sosial di sebagain besar daerah di Pulau Lombok, Desa Rimbo Panjang juga merupakan daerah dengan kutur dan budaya yang beragam. Namun, situasi yang terjadi selama hampir dua tahun yang disebabkan oleh pandemi covid-19 telah menyebabkan penurunan penghasilan dan daya beli mereka, menurut (Yanti et al., 2018; Sudrajat et al., 2019) modal dari segi sumber daya (resources) terbagi menjadi modal finansial (financial capital), modal fisik (physical capital), modal manusia (human capital) dan modal sosial (social capital). Sumber modal sosial bukanlah berasal dari sumber modal lainnya yang biasanya kita ketahui berasal dari pinjaman bank, pemerintah, dan lain-lain. Namun yang dimaksud sebagai sumber modal sosial merupakan berasal dari hubungan-hubungan atau relasi sosial yang pastinya harus ada koneksi dengan orang lain, maksudnya harus memiliki hubungan antar satu sama lain.

Di samping itu, cuaca yang tidak pasti turut berkontribusi pada ketidakpastian hasil dari lahan yang mereka olah. Persoalan berikutnya, area pertanian yang menjadi penopang hidup sehari-hari mendapatkan ancaman dari gempuran pembangunan permukiman serta berbagai fasilitasnya. Hal ini berdampak pada kualitas lahan pertanian yang menjadi kurang baik terutama sejak sekitar 10 (sepuluh) tahun terakhir. Jika alih fungsi lahan menjadi permukiman serta fasilitas lainnya yang terus terjadi maka situasi ini menimbulkan resiko kerentanan penghidupan petani di Rimbo Panjang khususnya yang menjadi sasaran kegiatan pengabdian. Satu diantara akar masalahnya dengan melakukan penimbunan maupun pembuatan kanal yang menyebabkan lahan gambut di sekitarnya menjadi kering. Apalagi di tambah dengan merebaknya wabah Virus Korona di wilayah desa Rimbo Panjang membuat hasil olahan keripik nanas dan dodol nanas mengalami kerugian karena kurang dilirik oleh pembeli, Kurangnya inovasi dalam pembuatan produksi buah nanas. Produksi menumpuk tetapi penjualan cenderung tidak merangkak naik.

\subsection{Pelaksanaan Edukasi dan Sosialisasi Desa Partisipasif}

Kami mengupayakan serangkaian aksi edukasi dan sosialisasi mengenalkan penguatan modal sosial. Upaya ini dilandaskan pada analisis situasi maupun hasil telaah lapangan yang telah kami temukan. Potensi resiko keretanan ekonomi pada rumah tangga petani yang menjadi sasarana kegiatan pengabdian akan semakin besar seiring gejolak ketidakpastian akibat Covid-19 yang 
didukung oleh faktor alam, pembinaan Kemasyarakatan Desa sebagai bagian dari kewenangan lokal berskala Desa dalam hal ini adalah pelaksanaan tanggung jawab Desa dalam memelihara ketentraman dan ketertiban. Hasil temuan peneliti, pada pembinaan kemasyarakatan pemerintah desa dalam hal menjaga ketentraman dan ketertiban masyarakat pemerintah desa baru secara prosedural melakukan koordinasi dengan aparat setempat dan tim satgas yang ada di sana Pemerintah desa belum berhasil melibatkan seluruh unsur masyarakat termasuk untuk bersamasama menjaga ketentraman dan ketertiban Desa. melestarikan dan mengembangkan gotong royong masyarakat Desa.

Kegiatan penelitian terhadap kelompok usaha POKMAS dilaksanakan selama dua tahun dimulai dengan upaya meningkatkan pengetahuan kelompok masyarakat nenas berduri pada tahun pertama, implementasi, evaluasi dan pendampingan serta dan penguatan sistem perkembangan dan pertumbuhan pada tahun kedua,. Pertemuan dengan kelompok pelaku usaha nenas berduri dalam bentuk sosialisasi dan pelatihan. Kegiatan awal yang dilakukan berupa diskusi dan sosialisasi terkait permasalahan dalam kelompok pelaku usaha nenas berduri terkait kendala kegiatan usaha serta dalam pengembangan modal sosial untuk usaha nenas. Kewenangan pemberdayaan masyarakat desa dilakukan dengan mendampingi masyarakat agar lebih berdaya dalam hal pengelolaan hasil usaha. Hasil temuan peneliti, dimana pemerintah desa berupaya memberdayakan seluruh masyarakat desa melalui berbagai program kewirausahaan salah satunya melalui kelompok usahaa POKMAS nenas berduri. Selain itu kepala desa Rimbo Panjang juga turut melakukan beberapa himbauan dan penyuluhan bersama kader-kader desa dalam menanggulangi penyebaran wabah Virus korona (Covid-19). (Soetomo, 2012; Soekanto, 2013; Achmad, 2021). Peningkatan kapasitas masyarakat melalui usaha ekonomi produktif, kelompok masyarakat miskin, kelompok pengrajin, kelompok tani, di nilai sudah berjalan sesuai harapan pemerintah setempat namun dengan adanya pandemi yang sedang melanda hampir seluruh wilayah Kota Pekanbaru termasuk di desa Rimbo Panjang membuat berbagai aspek kehidupan masyarakat menjadi tertunda.

\subsection{Hasil}

Berdasarkan pembahasan yang telah dipaparkan, maka penulis dapat menarik kesimpulan bahwa, kelompok usaha nenas berduri sekaigus responden dalam pengabdian ini pada dasarnya memiliki ketertarikan serta memahami manfaat teknologi untuk mengembangkan berbagai usahanya, di antaranya dengan meningkatkan produktivitas dan softskill meskipun ditemukan kendala dasar yakni penguasaan gadget yang kurang dan kemungkinan penggunaan data seluler dalam jumlah besar. Kemudian Peningkatan dari hasil produksi olahan buah nanas karena pemanfaatan teknologi dapat meningkatkan penghasilan masyarakat karena pemanfaatan olahan nenas menjadi lebih optimal dan dapat memanfaatkan berbagai macam jenis komoditas yang ada di dalamnya. Optimalisasi ini untuk meningkatkan hasil dari produksi masyarakat di berbagai komoditas agar dapat meningkat dan dapat meminimalisir resiko kerugian yang terjadi akibat gagal produksi karena diversifikasi komoditas, maupun karena faktor bencana non alam yakni pandemi Covid-19, para pelaku usaha nenas berduri di desa Rimbo Panjang sangat antusias dalam mengambil perannya dalam pemanfaatan jejaring teknologi dan pengembangan modal sosial, pada kelompok usaha nenas berduri sehingga masyarakat dapat lebih memahami bidang-bidang teknologi, terutama pada pemanfaatan pengolahan hasil buah nanas karena motivasi yang timbul dari diri masyarakat yang berporofesi sebagai pengusaha nenas.

\section{Daftar Pustaka}

Achmad, W. (2021). Citizen and Netizen Society: The Meaning of Social Change From a Technology Point of View. Jurnal Mantik, 5(3), 1564-1570.

Achmad, W. RW (2021). Conflict Resolution of Remote Indigenous Communities (Overview of The Sociology Communication). LEGAL BRIEF, 10(2), 280-286.

Adisasmita, R. (2006). membangun desa partisipatif. Yogyakarta: Graha IImu.

Athhoff, M. R. (2013). Pengantar sosiologi politik. Jakarta: PT Raja Grafindo Perada.

Basem, Z. (2015). Manajemen Agribisnis Sustainable. Medan: Larispa Indonesia.

Dadi, D. (2014). Peran Wanita dalam perspektif sosio-demografis pada masyarakat adat kuta di Kecamatan Tambaksari, Kabupaten Ciamis, Jawa Barat. LITERASI: Indonesian Journal of Humanities, 2(1), 49-57. 
Dadi, D. (2019). Local Ecology-Based Agroforestry Management: Building Effectiveness of Knowledge-Based Wetland Management. Jurnal Mantik, 3(3), 170-176.

Dadi, D. (2020). Community Characteristics of Brown Planthopper (Nilaparvata lugens Stal) Predator Arthropoda Community in Agroforestry-Based Rice Fields. Budapest International Research in

Dadi, D. (2020). Leuwikeris Agricultural Development In Supporting The Development Of Ecological Agriculture In Ciamis District. Enrichment: Journal of Management, 11(1, Novembe), 218-222

Dadi, D. (2021). Oil Palm Plantation Expansion: An Overview of Social and Ecological Impacts in Indonesia. Budapest International Research and Critics Institute (BIRCI-Journal): Humanities and Social Sciences, 4(3), 6550-6562.

Damsar. (2009). Pengantar Sosiologi Ekonomi. Kencana Prenada Media Group.

Damsar. (2015). Pengantar Teori Sosiologi. Jakarta: Prenada Media Group.

Exact Sciences (BirEx Journal), 2(4), 539-547.

Kunyanti, S. A., \& Mujiono, M. (2021). Community Empowerment-based Corporate Social Responsibility Program in Panglima Raja Village. International Journal on Social Science, Economics and Art, 11(1), 12-19.

PrawiraW, R., Maulida, H., \& Achmad, W. (2021). Narrating the Implementation of Social Welfare Community Program. Review of International Geographical Education Online, 11(5), 228-235.

Sidiq, R. S. S., \& Achmad, R. W. W. (2020). Gender aspects in remote indigenous community empowerment program in Indonesia. Journal of Advanced Research in Dynamical and Control Systems, 12(6), 21042109. https://doi.org/10.5373/JARDCS/V12I6/S20201172

Sidiq, R. S. S., Jalil, A., \& Achmad, R. W. W. (2021). Virtual World Solidarity: How Social Solidarity is Built on the Crowdfunding Platform Kitabisa. com. Webology, 18(1), 192-202.

Soekanto, Soerjono. 2013. Sosiologi Suatu Pengantar. Jakarta: Rajawali Pers

Soetomo. (2012). pembangunan masyarakat merangkai sebuah kerangka. yogyakarta: pustaka pelajar.

Sudrajat, A. R., Sumaryana, A., Buchari, R. A., \& Tahjan, T. (2018). Perumusan Strategi Pengelolaan Pasar Tradisional di Kabupaten Sumedang. JPPUMA: Jurnal IImu Pemerintahan dan Sosial Politik UMA (Journal of Governance and Political Social UMA), 6(1), 53-67.

Sudrajat, A. R., Sumaryana, A., Buchari, R. A., \& Tahjan, T. (2019). Pengamatan Lingkungan Pengelolaan Pasar Tradisional di Kabupaten Sumedang. Jurnal Administrasi Publik: Public Administration Journal, 9(1), 31-42.

Syafrizal, S. (2019). Pengembangan Potensi Dusun lii Teluk Jering Menjadi Kawasan Wisata Berbasiskan Culture Daerah Aliran Sungai Kabupaten Kampar.

Syafrizal, S., \& Resdati, R. (2020). Partisipasi Masyarakat dalam Restorasi Gambutdi Desa Rimbo Panjang. Journal of Education, Humaniora and Social Sciences (JEHSS), 3(2), 712-720.

Syafrizal, S., \& Resdati, R. (2021, February). RESTORASI GAMBUT BERBASIS PEMBEDAYAAN MASYARAKAT. In PROSIDING SEMINAR NASIONAL LPPM UMP (pp. 596-601).

Yanti, R., Syahza, A., Hidir, A., \& Suwondo, S. (2018). The communication model of forest management based on environmental awareness. Management of Environmental Quality: An International Journal. 